ELWIRA WARDA* - LUBLIN

\title{
DZIEJE BIBLIOTEKI ARYSTOTELESA
}

W rejonie kulturowym Morza Śródziemnego, w pierwszym okresie rozwoju książki, kiedy wygląd edytorski książki był zupełnie odmienny od formy obecnej ${ }^{1}$, powstawały niewielkie księgozbiory. Niektórzy z panujących - niektóre źródła historyczne wskazują na tyranów greckich Pizystrata i Polikratesa - posiadali swoje księgozbiory. Istnienie biblioteki na dworze Pizystrata potwierdził pisarz rzymski Aulus Gellius ${ }^{2}$ oraz Izydor z Sewilli ${ }^{3}$ Ich świadectwa opierają się najprawdopodobniej na dziele uczonego rzymskiego Warrona z I w. p.n.e. De bibliothecis. Pewniejsze informacje posiadamy, gdy chodzi o historię książek wieków późniejszych, kiedy zaczynają powstawać księgozbiory filozofów i uczonych.

* Elwira Warda - mgr filozofii, bibliotekarz w Bibliotece Uniwersyteckiej KUL.

${ }^{1}$ Starożytni Grecy i Rzymianie znali książkę w formie zwoju. Zwój tworzyła zwinięta w rulon taśma papirusu, na której umieszczano tekst w poprzecznych kolumnach. Zwoje zaopatrzone w drążek umieszczano w glinianych naczyniach; czasem w pokrowcach, a na zewnątrz zwisała karta z wypisanym tytułem, index. Czytelnik rozwijał trzymany w prawej ręce zwój, lewą ręką zwijał z powrotem część już przeczytaną. Dla ponownego przeczytania książki trzeba było cały zwój przewinąć $z$ lewej strony na prawą. W II w. p.n.e. do wytwarzania książek zaczęto używać pergaminu. Początkowo zwijano pergamin w rulon, podobnie jak papirus, później formowano z niego tzw. codex, w kształcie dzisiejszej książki.

${ }^{2}$ Aulus Gellius - II połowa II w. n.e. - uczony i pisarz rzymski, miłośnik starożytności i kolekcjoner ciekawostek. Pod koniec życia wykorzystał swoje notatki i napisał dzieło w dwudziestu księgach pt. Noce Attyckie. Do naszych czasów zachowało się 19 ksiąg (jedna zaginęła). Każdy rozdział Nocy Attyckich poświęcony jest innemu zagadnieniu z zakresu języka, literatury, kultury, prawa i życia codziennego starożytnej Grecji i Rzymu. Autor obficie cytuje dzieła sobie znane, lecz dzisiaj zaginione. $Z$ tego powodu Noce Attyckie są bezcenną kopalnią wiedzy o starożytności grecko-rzymskiej.

${ }^{3}$ Izydor z Sewilli (ok. 560-636) - święty Kościoła katolickiego; mówiono o nim, że polotem dorównywał Platonowi, wiedzą - Arystotelesowi, wymową - Cyceronowi, nauką - św. Augustynowi, a jego świętość życia porównywano do św. Grzegorza Wielkiego. Największym dziełem, jakie zostawił, to Codex etimologiarum - próba pierwszej naukowej encyklopedii, ogólnej syntezy wiedzy, jaką za jego czasów posiadano. 
Aby mogło dochodzić do tworzenia książnic musiały zaistnieć odpowiednie warunki. Na przełomie wieków V i IV p.n.e. do Aten przybywali wędrowni nauczyciele, którzy przygotowywali obywateli do życia publicznego. Byli to sofiści. Uczyli oni przede wszystkim wymowy i tym samym dali początek retoryce, która w późniejszym okresie była ważnym elementem nauczania. Czym jest sofistyka? Odpowiedź wymaga osadzenia tego pytania w realiach historycznych Grecji. Zjawisko to wyrosło w określonych warunkach społeczno-politycznych i kulturowych w Atenach II połowy V wieku p.n.e. Na mapie politycznej ówczesnej Grecji doszło do zasadniczych zmian, które dokonały się w wyniku wojen perskich. Ateny odegrały w nich decydującą rolę, a zwycięstwo nad Persami zapewniło im hegemonię w świecie greckim. Wzrosło również znaczenie polityczne i ekonomiczne miasta. Z końcem wojen perskich ukształtowała się ostatecznie w Atenach nowa struktura polityczna - demokracja. Stawiała ona przed obywatelem określone zadania polityczno-społeczne, którym musiała sprostać. Czy Ateńczycy do realizowania tych zadań byli odpowiednio przygotowani? Czy dotychczas funkcjonujący model wychowania i wykształcenia wystarczał w tych zmienionych warunkach?

W wieku V p.n.e. zmiany historyczne spowodowały, że potrzebny był taki model wychowania, który kształtowałby człowieka-obywatela. Demokracja ateńska wymagała od obywateli wykształcenia i wiedzy. Wówczas tylko osoba, która miała jasny obraz otaczającego ją świata, mogła orientować się w polityce i mogła przekonać innych o słuszności głoszonych poglądów. Potrzeby państwa demokratycznego zmieniły się. W nowej sytuacji zaistniała konieczność ustalenia obowiązków obywatela wobec państwa. W demokratycznych Atenach powstały warunki sprzyjające działalności ludzi, którzy podjęli się nowego sposobu kształcenia i wychowania. Potrzebna była wiedza, a więc znajomość dialektyki, gramatyki, retoryki, matematyki, astronomii, historii, poezji, wiedzy o państwie, prawie i strategii. W Atenach powstawały liczne szkoły, w których kształciła się młodzież, pragnąca zdobyć sprawność w mówieniu, jak $i$ w działaniu.

Na powstawanie księgozbiorów miał wpływ rozwój dramatu (Ajschylos, Sofokles, Eurypides, Arystofanes), prozy historycznej (Herodot, Tucydydes), wymowy (Demostenes) oraz filozofii (Platon i Arystoteles). Książki zbierali sofiści i ich uczniowie, podręczny księgozbiór posiadał każdy nauczyciel w szkole. Twórczość poetycka wymagała czasem bogatej biblioteki, jak również odpowiedniego aparatu pomocniczego potrzebnego przy prowadzeniu jakiejkolwiek pracy naukowej.

Około roku 387 p.n.e. Platon ${ }^{4}$ założył w zakupionym przez siebie gaju oliwnym, który początkowo poświęcony był Akademosowi ${ }^{5}$, własną szkołę filozoficzną zwaną Akademią. W krótkim czasie stała się ona sławnym miejscem spotkań

${ }^{4}$ Platon, właśc. Aristokles (ok. 427-347 p.n.e.)- jeden z najwybitniejszych greckich filozofów starożytności. W 387 r. p.n.e. założył Akademię Ateńską. Był twórcą systemu filozoficznego zwanego idealizmem. Od niego zaczyna się właściwa filozofia europejska, rozumiana jako systematyczna nauka.

${ }^{5}$ Heros w mitologii greckiej. 
intelektualistów, a po śmierci Platona istniała jeszcze dziewięćset lat ${ }^{6}$, podczas których miewała okresy lepsze i gorsze. Akademia Platońska to pierwowzór uniwersytetu, kształcący w zakresie filozofii, matematyki i astronomii. Napis nad wejściem do niej głosił, że nie mają tam wstępu niewykształceni w matematyce.

Ateny wieków V i IV p.n.e. były miejscem jednego z najpłodniejszych okresów w historii kultury. Każdy wykształcony obywatel miasta-państwa umiał czytać i pisać. Mimo iż czytelnictwo w Helladzie rozwijało się powoli, jednak coraz więcej ludzi obcowało z książkami i coraz więcej osób je posiadało. Z historii wiadomo, iż Platon był rozmiłowany w księgach i gromadził je, lecz jego księgozbiór nie był zbyt obszerny. Natomiast w Liceum, powołanym do życia przez Arystotelesa ze Stagiry, konieczność korzystania z książek stała się bardziej widoczna. Arystoteles przygotował bogaty oraz różnorodny materiał jako podstawę do swoich wykładów i to jego uważa się za pierwszego prawdziwego zbieracza książek.

Arystoteles urodził się w 384 roku p.n.e. w Stagirze, mieście leżącym na Półwyspie Chalcydyckim. W chwili jego narodzin Stagira była niezależnym miastem jońskim, członkiem Ateńskiego Związku Morskiego. Jego ojciec Nikomach był lekarzem króla Amyntasa II, ojca Filipa Macedońskiego, a matka Olimpias prawdopodobnie pochodziła z rodziny lekarskiej. Po śmierci rodziców siedemnastoletni Arystoteles przybywa do Aten i wstępuje do Akademii Platońskiej, gdzie spędza dwadzieścia lat, najpierw jako uczeń, a później jako nauczyciel. Już jako student Arystoteles odznaczał się dojrzałością umysłu i zapewne z tego powodu Platon nazywał go czytelnikiem albo rozumem. W Akademii Stagiryta podejmował samodzielne wykłady, przede wszystkim na tematy retoryczne, rywalizując z Isokratesem ${ }^{7}$. Z tym okresem wiążą się jego pierwsze pisma filozoficzne Eudemos i Protreptikos. Po śmierci Platona Arystoteles opuścił Ateny i udał się do Assos, miasta leżącego na wybrzeżu Troady, w którym rozpoczął systematyczne wykłady z metafizyki, etyki oraz polityki. Tutaj powstał zarys jego dzieła $O$ niebie. W 343 roku p.n.e. Arystoteles przeniósł się na wyspę Lesbos i po krótkim pobycie powrócił do Aten. Rozpoczął tworzenie szkoły filozoficznej, lecz w trakcie prac organizacyjnych otrzymał od króla Filipa II propozycję objęcia funkcji wychowawcy jego syna Aleksandra. Wyraził zgodę i udał się na dwór królewski do Pelli. Dla Aleksandra Macedońskiego specjalnie przygotowywał teksty i pragnął wykształcić swego ucznia na władcę wszystkich Hellenów. Uważał, że jeśli Grecja zjednoczy się pod władzą przywódcy, którego zdolności polityczne oraz cechy moralne zjednałyby mu powszechne uznanie, może opanować cały świat. W Aleksandrze widział kandydata na takiego panhelleńskiego władcę. Wyrazem tego przekonania było pismo $O$ władzy królewskiej.

W roku 335 p.n.e. we wschodniej części Aten, w Gimnazjonie Lykeion przed bramą Diocharesa Arystoteles założył własną szkołę, Liceum. Jej uczniów nazywano perypatetykami (gr. peripatetikos = przechadzajacy się), gdyż nauka odby-

${ }^{6}$ Akademia Platońska została zamknięta w 529 roku przez cesarza Justyniana I Wielkiego.

${ }^{7}$ Isokrates (436-338 p.n.e.) - mówca grecki, nauczyciel wymowy, twórca klasycznej prozy attyckiej, zaliczany do kanonu dziesięciu mówców. Około 390 r. p.n.e. założył w Atenach szkołę retoryczną, która była pierwszą szkołą dla kształcenia średniego. 
wała się w trakcie spacerów. W Liceum Arystoteles spędził ostatnie trzynaście lat swego pracowitego życia w gronie uczniów i współpracowników, gdzie dokonał imponującej swym zasięgiem organizacji nauk: zarówno przyrodniczych, jak i humanistycznych. Obok naukowych wykładów rozwinął twórczość literacko-naukową, o czym świadczy duża ilość tytułów obejmująca 143 dzieła w 400 księgach, nie licząc listów i poezji.

Liceum było ośrodkiem naukowym, w którym znajdowały się sale wykładowe, zbiory różnych materiałów, pomoce naukowe oraz biblioteka. Panował w nim kult wysiłku badawczego. Przekazany przez Diogenesa Laertiosa ${ }^{8}$ testament Arystotelesa potwierdza istnienie takich zbiorów. W Liceum prace wykonywano w wyspecjalizowanych zespołach, a zakres dociekań naukowych był ogromny: obejmował historię społeczeństwa, literatury i sztuki, historię dawnych systemów politycznych oraz ich krytykę, wszystkie dziedziny nauk matematycznych oraz przyrodniczych.

Nagła śmierć Aleksandra w 323 r. p.n.e. wywołała wzrost nastrojów antymacedońskich. Wobec wzmagających się wrogich zachowań Arystoteles opuścił miasto, przeniósł się do Chalkis na Eubeę, gdzie kilka miesięcy później zmarł (322 r. p.n.e.).

Zgodnie z duchem ostatnich lat mistrza szkoła chciała ściśle służyć celom naukowym, a zainteresowania filozoficzne perypatetyków zeszły na drugi plan. Teofrast pozostawił epokowe, godne prac zoologicznych Arystotelesa prace botaniczne. Eudemos z Rodos ${ }^{9}$, należący wraz z Teofrastem do najbliższych uczniów Stagiryty, słynny był ze swojej encyklopedycznej wiedzy, a szczególniej odznaczył się jako historyk matematyki. Arystoksenos z Tarentu doprowadził do szczytu wiedzę starożytnych o muzyce; prowadził dalej badania pitagorejczyków, ale stosując metodę empiryczną Arystotelesa. Dikajarchos z Messany ${ }^{10}$ na Sycylii położył duże zasługi na polu geografii, historii kultury oraz polityki.

Przed śmiercią w roku 322 p.n.e. Arystoteles przekazał swemu następcy Teofrastowi z Eresos bibliotekę obejmującą również jego spuściznę rękopiśmienną. W Perypacie aż do śmierci Teofrasta w 287 r. p.n.e. podstawą nauczania były wykłady Arystotelesa. Później biblioteka Stagiryty dostała się w ręce Neleusa ze Skepsis w Troadzie, którego potomkowie przechowywali ją w piwnicy w bardzo złych warunkach. Jedna z wersji głosi, iż ukrywając księgi pragnęli w ten sposób ocalić rękopiśmienną spuściznę Arystotelesa przed chciwością Attalidów, którzy wówczas zakładali Bibliotekę Pergameńską. Około roku 100 p.n.e. księgozbiór Arystotelesa odkrył i zakupił Apellikon z Teos, bogaty kupiec kolekcjonujący starożytne księgi. Przewiózł go do Aten i rozpowszechniał w odpisach. Jednakże niezbyt długo ów księgozbiór pozostał w Atenach, gdyż około 86 roku p.n.e. stał się częścią łupu wojennego Sulli, który wywiózł go do Rzymu. Według niektórych źródeł starożytnych to w Rzymie po raz pierwszy dzieła Arystotelesa wydał

\footnotetext{
${ }^{8}$ Diogenes Laertios, Żywoty i poglądy słynnych filozofów, PWN, Warszawa 1982.

${ }^{9}$ Eudemos z Rodos (IV w. p.n.e.) - autor komentarzy do Fizyki Arystotelesa zachowanych tylko we fragmentach.

${ }^{10}$ Dikajarchos (IV w. p.n.e.) - uczeń Arystotelesa, filozof perypatetyczny, wszechstronny uczony. Napisał dzieło historyczne Żywoty Grecji, które zawierało opisy ustroju państw greckich.
} 
gramatyk Tyrannion. Jednakże dopiero Andronikos z Rodos ${ }^{11}$ dokonał krytycznego wydania dzieł Arystotelesa, skatalogował jego spuściznę, zbadał autentyczność poszczególnych pism, uporządkował je wedle przynależności do różnych nauk oraz był pierwszym, który je komentował. Na wydaniu Andronikosa opierały się inne starożytne wydania, a jedno z nich jest źródłem naszych rękopisów. Wersji tej przeciwstawia się inna, przekazana przez Atenajosa pod koniec II wieku p.n.e., która głosi, że księgozbiór Filozofa ze Stagiry zakupił u Neleusa Ptolemeusz Filadelfos ${ }^{12}$, założyciel Biblioteki Aleksandryjskiej. Istotnie, Biblioteka w Aleksandrii posiadała znaczną część dzieł Arystotelesa. Nawet gdyby odrzucić tę wersję, to nie można zaprzeczyć, że poglądy filozoficzne Perypatu, także stoików II i I wieku p.n.e., świadczą o znajomości dzieł Arystotelesa. Za przykładem Andronikosa wielu perypatetyków zaczęło komentować dzieła Stagiryty. Najwybitniejszym z nich był Aleksander z Afrodyzji. Działalność komentatorską uprawiali także Porfiriusz (II w.) oraz Simplikios (łac. Symplicjusz - w VI w.), który pisał komentarze nie tylko do dzieł Arystotelesa, lecz również Platona i Epikteta. Dzieła Simplikiosa z racji dużej ilości fragmentów cytowanych w komentarzach do Arystotelesa są cennym źródłem do poznania filozofii greckiej. Pisma Stagiryty komentowano także na Zachodzie Europy, przekładano je na łacinę, ale tylko niektóre pisma logiczne, a u progu wieków średnich na czoło badań nad twórczością Filozofa wysunął się Boecjusz ${ }^{13}$. Komentatorom Arystotelesa przypadło nie tylko objaśniać, ale i uzupełniać jego poglądy. Tylko bowiem poglądy logiczne, przyrodnicze oraz etyczne twórca Liceum pozostawił w postaci mniej więcej wykończonej, natomiast metafizyczne zaledwie naszkicował. Liceum jako szkoła została ostatecznie zniszczona w roku 84 . W roku 529 n.e. po zamknięciu przez cesarza Justyniana Akademii Platońskiej i innych ateńskich szkół filozoficznych, myśl grecka szukała schronienia na Wschodzie, a dopiero w wieku XII pojawiła się na Zachodzie Europy.

Wpływ arystotelizmu był inny w starożytności, a inny w chrześcijaństwie. W starożytności ze spuścizny Arystotelesa znamy tylko pisma przeznaczone dla szerszych kół; późniejsze zaś pozostawały nie wydane. Epoka chrześcijańska odziedziczyła jedynie jego pisma późne, które u schyłku starożytności zostały odnalezione i wydane.

Po upadku Grecji pisma Arystotelesa przechowały się najpierw w Syrii, gdzie liczni chrześcijanie uczyli się greki, aby móc czytać Nowy Testament i pisma Ojców Kościoła ${ }^{14}$. Tłumaczono na rodzimy język dzieła myślicieli greckich. Już w IV

\footnotetext{
${ }^{11}$ Andronikos z Rodos (I w. p.n.e.) - dziesiąty po Arystotelesie scholarcha Liceum.

${ }^{12}$ Ptolemeusz II Filadelfos (283-247 p.n.e.) - za jego panowania przetłumaczono na język grecki część Starego Testamentu.

${ }^{13}$ Boecjusz, Annicius Manlius Severinus Boethius (ok. 475-524 r. n.e.) - filozof, mąż stanu i pisarz łaciński. Za panowania Teodoryka był konsulem rzymskim. Popadł w niełaskę, został uwięziony i stracony. W czasie pobytu w więzieniu napisał słynne dzieło O pocieszeniu, jakie daje filozofia (Consolatio philosophiae). Przełożył na łacinę logikę Arystotelesa. Napisał podręczniki muzyki, arytmetyki, astronomii i geometrii.

${ }^{14}$ Ojcowie Kościoła (łac. Patres) - teologowie we wczesnym chrześcijaństwie (do VIII wieku): św. Ambroży (IV w.), św. Grzegorz Wielki (VI w.), św. Augustyn z Hippony (V w.) i Maksym Wy-
} 
w. n.e. w Edessie na terenie Mezopotamii, a następnie w Arabii, czytano Arystotelesa, Galena i ich komentatorów. A gdy państwo wyznawców Mahometa opanowało Hiszpanię, ich uczeni przynieśli naukę Arystotelesa na Półwysep Pirenejski, do Kordoby, gdzie istniał uniwersytet. Jednakże wędrówka na Zachód odbywała się przede wszystkim dzięki filozofom arabskim, Awicennie ${ }^{15}$ i Awerroesowi ${ }^{16}$, chociaż pewne zasługi w tym zakresie poniósł wybitny filozof żydowski - Majmonides. Jednakże dopiero w XII i XIII wieku Europa łacińska zapoznała się z całą istniejącą spuścizną myśli Arystotelesa. Należy pamiętać, że w pierwszej połowie XIII wieku rozwój studiów arystotelicznych hamowały kościelne zakazy czytania i komentowania pism Arystotelesa na głównej uczelni Europy, w Paryżu. Uniwersytet ów był wówczas centralnym ośrodkiem ruchu umysłowego. Zakazy te ograniczały się do czasu, kiedy pisma Arystotelesa zostaną oczyszczone od podejrzenia błędności. Z historii filozofii wiemy, że aktu chrystianizacji myśli arystotelesowskiej dokonali Albert Wielki ${ }^{17}$ i Tomasz z Akwinu ${ }^{18}$, a Filozof ze Stagiry we wszystkich dziedzinach filozofii stał się największym autorytetem. Gdy pisano Filozof bez bliższego określenia znaczyło to po prostu Arystoteles.

Znajomość Arystotelesa z „pierwszej ręki” zaczyna się dopiero w wieku XIV. W epoce renesansu Europa Zachodnia powraca do kultury klasycznej Grecji i do znajomości greki. W odrodzeniu po raz pierwszy ukazują się drukiem niektóre pisma Arystotelesa, początkowo w przekładach, później w oryginale. Był to kulminacyjny okres zainteresowania poglądami myślicieli starożytności, zwłaszcza w wieku XVI - apogeum działalności przekładowej i komentatorskiej. Zainteresowanie filozofią Arystotelesa w XVII i XVIII wieku uległo osłabieniu.

O Arystotelesie w świecie uczonych zrobiło się głośno pod koniec wieku XIX. Był to okres wielkich odkryć oraz intensywnych prac archeologicznych. W Egipcie, w suchych piaskach pustyni przechowały się pisane na papirusie urywki najrozmaitszych tekstów ze starożytności. W 1880 roku do Muzeum Berlińskiego zakupiono papirusy pochodzące z Fajum. Między nimi znalazły się dwie kartki zapisane po obu stronach. ${ }^{19}$ Rok później T. Bergk wyraził przypuszczenie, iż są to

znawca, który był świętym Kościoła katolickiego i prawosławnego.

${ }^{15}$ Awicenna, Ibn Sina (ok. 980-1037) - znany lekarz; jego dzieło to Kanon medyczny (Canon medicinae). W Księdze uzdrowienia wyjaśnia doktryny Arystotelesa i innych filozofów, dzięki tym dokonaniom otrzymał przydomek Dowód Prawdy.

${ }^{16}$ Awerroes, Ibn Ruszd (1126-1198) - arabski filozof i uczony. Zajmował ważne stanowiska administracyjne pod rządami muzułmańskich władców Hiszpanii. Napisał rozprawy z medycyny i filozofii. Sławę przyniosły mu komentarze do dzieł Arystotelesa, takich jak $O$ duszy i Metafizyka.

${ }^{17}$ Albert Wielki (ok. 1205-1280), święty, filozof scholastyczny, teolog, dominikanin, doktor Kościoła - znany jako doctor universalis lub doctor expertus. Jako jeden z pierwszych w sposób systematyczny łączył filozofię Arystotelesa z teologią katolicką. Jego uczniem był Tomasz z Akwinu.

${ }^{18}$ Tomasz z Akwinu (1225-1274), święty - dominikanin, filozof i teolog, jeden z najwybitniejszych myślicieli w dziejach chrześcijaństwa. Napisał komentarze do dzieł Arystotelesa. Po śmierci otrzymał tytuł doctor angelicus. W 1323 roku został kanonizowany przez papieża Jana XXII.

${ }^{19}$ Były one niewielkich rozmiarów: $13,2 \times 13,8 \mathrm{~cm}$ i $18 \times 10 \mathrm{~cm}$. 
fragmenty Ustroju politycznego Aten. Przypuszczenie to okazało się słuszne ${ }^{20}$. W styczniu 1891 roku w papirusach nabytych przez British Museum w Londynie została odnaleziona niemal w całości Politeja ateńska. W marcu tegoż roku ukazała się podobizna całego rękopisu na 22 tablicach. Nie wiadomo, z jakiej miejscowości Egiptu pochodził odkryty rękopis, który obejmuje cztery zwoje zapisane po obu stronach. Na stronie wewnętrznej (recto) znajdowały się zapiski wydatków i dochodów gospodarskich ${ }^{21}$. Kiedy zapisane informacje straciły znaczenie, ze względów oszczędnościowych na przepisanie Ustroju politycznego Aten użyto zewnętrznej strony zwoju (verso). Jest to odpis prywatny ${ }^{22}$.

Do zachowanych dzieł Arystotelesa należą między innymi: Fizyka, Metafizyka, Etyka Nikomachejska, Etyka Wielka, Polityka, Poetyka, Retoryka. Arystoteles był jednym z najbardziej wszechstronnych myślicieli greckich, stworzył podstawy rozwoju wielu nauk szczegółowych. Wiele jego pism zaginęło, może uległy zniszczeniu, a może jednak kiedyś, dzięki szczęśliwemu zrządzeniu losu, odnajdzie się jakieś zaginione dzieło i będzie można dopisać kolejny etap wędrówki ksiąg i myśli założyciela Liceum.

\footnotetext{
${ }^{20}$ Okazało się, że tekst zachowany na papirusie berlińskim obejmuje rozdziały XII 4; XIII 1-5; XXI 4 i XXII 4-7.

${ }^{21}$ Zapiski Didymosa, zarządcy majątku Epimachosa, leżącego niedaleko miasta Hermopolis. Pochodziły one z roku 10 i 11 panowania cesarza Wespazjana, czyli z lat 78 i 79 n.e.

${ }^{22}$ Wskazuje na to także fakt, że pod koniec pierwszego zwoju znajduje się urywek objaśnień do mowy Demostenesa przeciwko Fidiaszowi, pisany w przeciwnym kierunku i przekreślony. Rozmiary czterech zwojów nie są jednolite. Jedynie trzy z nich mają szerokość $28 \mathrm{~cm}$ : I - długości $220 \mathrm{~cm}$ z 11 kolumnami tekstu, II - długości 166,5 cm z 13 kolumnami tekstu i 6 kolumn III tekstu o długości $91,5 \mathrm{~cm}$. Zwój czwarty zawiera 7 kolumn pisma, o szerokości $25 \mathrm{~cm}$ i długości $79 \mathrm{~cm}$. Pierwsze trzy zwoje zachowały się dosyć dobrze, chociaż tu i ówdzie są zatarte litery, zdarzają się również dziury. Zwój czwarty był połamany i kawałki z trudem udało się złożyć w całość. Jednak po złożeniu w papirusie pozostało wiele luk. Tekst Ustroju przepisywały cztery osoby. Wskazuje na to charakter pisma.
} 


\title{
THE HISTORY OF THE ARISTOTLE'S LIBRARY
}

\begin{abstract}
Summary
Reading in Hellas developed quite slowly in the first period of the book development. However, more and more people read and possessed books. History reveals that ancient Greeks possessed small book collections. One of them was Aristotle of Stagira who is considered to be the first real book collector. His library held 143 works in 400 books. Before his death, he bequeathed his whole book collection to Teofrast of Eresos. In the course of time the library "changed hands". It even became the part of Sulla's war loot and hence it was in Rome. The library in Alexandria also possessed a substantial part of Aristotle's books.

After the collapse of Greece, Aristotle's writings were kept in Syria. In the 4th century in Mesopotamia and then Aristotle's writings along with other Greek philosophers were read in Arabia. The expansion of his philosophy to the West was possible due to the expansion of the Mahomet's followers to the Pyrenees Peninsula. Thanks to the Arab philosophers, Latin Europe became acquainted with Aristotle's philosophical legacy.

At the end of the 19th century Aristotle was the talk of the world of science due to the new archeological discoveries. Dry sands of the Egyptian desert preserved papyruses with the fragments of different ancient texts. And thus Aristotle's "The Constitution of the Athenians" was discovered, the text whose title had been only known before this archeological find.
\end{abstract}

